\title{
DISCUSSIE
}

\section{Coronapandemie 2020: een kritisch perspectief}

\author{
Roel Pieterman
}

\section{Inleiding}

In zijn eerste 'historische' coronatoespraak op 16 maart 2020 spreekt Rutte ook over 'een muur om de zwakkeren' bouwen en zegt hij tegen deze mensen: 'Ik realiseer me dat u grote zorgen hebt. We proberen de risico's voor u zo klein mogelijk te maken' ${ }^{1}$ De beleidsprioriteit is ondubbelzinnig: het besmettingsgevaar zo veel mogelijk beteugelen, oftewel flattening the curve. In de meeste andere landen is ditzelfde patroon zichtbaar. Tekenend voor de overheersende focus op de bestrijding van het nieuwe coronavirus COVID-19 is dat het lang duurt voor het Outbreak Management Team (OMT), hét adviesorgaan van de regering, wordt aangevuld met andere experts dan virologen en epidemiologen. ${ }^{2}$

In deze bijdrage onderwerp ik deze eenzijdige beleidsfocus op COVID-19 als target risk aan een kritische analyse. Ik doe dat door de - over vrijwel de gehele wereld gevolgde werkwijze - voor Nederland aan een kosten-batenanalyse te onderwerpen. Het is immers belangrijk niet alleen naar de voordelen (baten) van het beleid te kijken, maar om ook de nadelen (kosten) in ogenschouw te nemen. Een vergelijking van de gevonden - geschatte! - voor- en nadelen van het beleid geeft antwoord op de vraag of het beleid doelmatig is.

In deze bijdrage stel ik de vraag of 'het redden van zwakke mensen' of concreter het voorkomen van een te grote toestroom van patiënten op de ic-afdelingen wel de juiste beleidsprioriteit is. Schaadde het grotendeels stilleggen van het maatschappelijk en economisch leven in het voorjaar de volksgezondheid niet meer dan dat zij erdoor werd bevorderd? En zou een herhaling daarvan in het najaar dat niet ook doen?

Hieronder ga ik allereerst in op het belang van kosten-batenanalyses. Daarna bespreek ik vier factoren die mijns inziens meer dan alle andere de doorslag zullen geven in de analyse. Dat is allereerst, om de kant van de baten/voordelen zichtbaar te maken, de vraag hoeveel gezonde levensjaren (qaly's; voor uitleg zie volgende paragraaf) het beleid opgeleverd heeft. Daarna ga ik in op de nadelen of kosten van het beleid in de vorm van de opportuniteitskosten ervan. Daarbij stel ik de vraag hoeveel qaly's de overheid zou hebben kunnen realiseren als de economische steunmaatregelen rechtstreeks in de volksgezondheid geïnvesteerd zouden worden. De vraag is of andere beleidsmaatregelen niet meer qaly's zouden hebben opgeleverd. Ten derde ga ik in op de vraag hoeveel qaly's verloren zijn gegaan door het uitstellen van de reguliere zorg voor patiënten met een andere 
ziekte. Ten vierde bespreek ik hoeveel qaly's verloren kunnen gaan bij mensen die (mogelijk langdurig) werkloos zullen zijn.

De uitkomsten van deze verschillende kwesties moeten met de nodige voorzichtigheid geïnterpreteerd worden. De pandemie duurt - in Nederland - bij het afronden van deze bijdrage begin oktober al ongeveer zeven tot acht maanden. De zoektocht naar betere behandelingen en geneesmiddelen heeft al wel enig succes opgeleverd, maar gaat net als die naar veilige en effectieve vaccins nog onverminderd door. In het najaar van 2020 worden weer volop mensen positief getest. Daarbij moet wel meteen bedacht worden dat zeer veel meer mensen getest worden dan in het voorjaar. Er belanden relatief minder mensen in (de ic-afdelingen van) ziekenhuizen. Bovendien is medio oktober, geheel anders dan in het voorjaar, (nog?) geen sprake van oversterfte. De grafieken van het RIVM laten duidelijk zien dat van voor- naar najaar het aantal positieve tests veel hoger is geworden, terwijl de aantallen ziekenhuisopnames en overlijdens juist heel laag blijven in september in vergelijking met maart en april. ${ }^{3}$ We weten dus weliswaar steeds meer over het virus, maar veel onzekerheid resteert. Voor ik mijn conclusies op basis van de vier vragen presenteer, ga ik daarom eerst nog in op onzekerheden en mogelijke andere factoren die in ogenschouw genomen moeten worden bij het overwegen van de betekenis van de antwoorden op de vragen.

\section{Het belang van kosten-batenanalyses}

Cruciaal in een kosten-batenanalyse (KBA) is dat er een duidelijke vergelijkingsmaatstaf gehanteerd wordt. Bij de bestrijding van COVID-19 staat de gezondheid van burgers voorop. Gezondheid, meer specifiek: volksgezondheid, dient dan ook de vergelijkingsmaatstaf te zijn in de KBA die ik hierna zal ondernemen. Het belang van het uitvoeren van een KBA ligt in het verkrijgen van inzicht in de doelmatigheid van het beleid. Doelmatigheid wordt van doorslaggevend belang geacht in alle overheidsbeleid en zeker ook in het domein van de volksgezondheid. Zo schrijft het Centraal Planbureau (CPB): 'Doelmatigheid betekent dat de beschikbare (financiële) middelen in de zorg zo worden ingezet, dat ze tot een zo hoog mogelijke gezondheid voor de samenleving leiden. Daarin heeft ook de overheid een rol, via het scheppen van de juiste randvoorwaarden.' Dat wil zeggen: bij de bestrijding van COVID-19 dient de overheid de middelen zo in te zetten, dat de volksgezondheid optimaal bevorderd wordt. Het CBP zegt het zo: 'Om tot goede en betaalbare gezondheidszorg te komen is het belangrijk om doelmatigheid na te streven. Dat betekent dat er geen verspilling van middelen mag zijn bij het uitvoeren van behandelingen en dat de middelen daar worden ingezet waar ze de meeste gezondheidswinst opleveren'. ${ }^{4}$ De Rijksoverheid zelf verwoordt het bij een toelichting op de 'Kwaliteit van wetten en regels' als volgt: 'Nieuwe wetten en regels moeten doeltreffend zijn en geen ongewenste effecten hebben'. ${ }^{5}$ Dat er in het kabinet een factie van vijf ministers is die 'al sinds het voorjaar [vindt] dat de

3 RIVM 9 oktober 2020.

4 CPB 18 maart 2015.

5 Rijksoverheid, zonder datum. 
coronapolitiek gedreven moet worden door méér dan alleen de zorgcapaciteit' is dus niet verwonderlijk. ${ }^{6}$

De vraag naar de doelmatigheid van het beleid ter bestrijding van COVID-19 luidt dus: hoe verhouden de positieve en negatieve effecten van het beleid op de volksgezondheid zich tot elkaar? De belangrijkste factoren bij het beantwoorden van deze vraag bespreek ik in volgende vier paragrafen.

Drie begrippen staan bij dit type analyse voorop: opportuniteitskosten, value of statistical life (VSL) en vooral quality adjusted life year (qaly). Opportuniteitskosten of alternatieve kosten verwijzen naar 'de kosten van een economische keuze uitgedrukt in termen van de beste gemiste kans: het waardeert de niet gerealiseerde opbrengst van het best mogelijke alternatief ten opzichte van de uiteindelijk genomen beslissing. ${ }^{7}$ Zoals eerder geformuleerd: is het mogelijk om met ander beleid meer volksgezondheid te genereren?

VSL is een statistisch berekende economische waarde die aan een mensenleven wordt toegekend. VSL is het getal - bedrag - dat naar voren komt als we burgers vragen hoeveel ze willen betalen voor een extra gezond levensjaar. De Stichting Wetenschappelijk Onderzoek Verkeersveiligheid (SWOV) wijst bijvoorbeeld op een studie naar de bereidheid om te betalen voor verbeterde verkeersveiligheid om daarmee levens te 'besparen'. Deze studie uit 2005 vindt een VSL tussen $€ 1,9$ en 2,5 miljoen. ${ }^{8}$ Als de overheid dit getal als maatgevend opvat, levert dat een maatstaf op om uitgaven voor verbetering van verkeersveiligheid vooraf op kosteneffectiviteit te toetsen. In 2006 pleit de Raad voor de Volksgezondheid en Zorg (RVZ) in het advies Zinnige en duurzame zorg voor toepassing van een VSL van $€$ zes miljoen als maatstaf om de kosteneffectiviteit van interventies in de volksgezondheid te beoordelen. ${ }^{9}$

$\mathrm{Nu}$ gaat het bij het redden van mensenlevens feitelijk maar zelden om het leven van een pasgeborene die nog een heel leven voor zich heeft. Daarom is het begrip qaly ontwikkeld. Dat verwijst naar een levensjaar in goede gezondheid. Bij een (medische) behandeling bepalen we het verwachte aantal qaly's door enerzijds te kijken naar het aantal naar verwachting resterende levensjaren en anderzijds naar de kwaliteit van leven tijdens deze jaren. ${ }^{10}$

De rekenkundige verhouding tussen VSL en qaly - die het mogelijk maken om beleidsmatig een verbinding te maken tussen economie en gezondheid - wordt bepaald door de levensverwachting in een samenleving. Dit zien we in het advies van de RVZ duidelijk terug:

'Deze [VSL levert] een indicatie [op] voor het antwoord op de vraag welk plafond gehanteerd zou moeten worden [voor de kosteneffectiviteit in de volks-

$6 \quad$ NRC Handelsblad 10 oktober 2020.

7 Wikipedia 29 mei 2020.

8 SWOV 2005.

9 RVZ 2006, p. 32-33. Voor meer uitleg: zie Wikipedia, 8 april 2020, waar naar belangrijke primaire bronnen wordt verwezen.

10 Voor meer uitleg: zie Wikipedia, 27 juli 2020, waar naar belangrijke primaire bronnen wordt verwezen. 
gezondheid]. Een bedrag van $€ 80.000$ per QALY is op grond van al deze gegevens verdedigbaar'. ${ }^{11}$

Helsloot, Pieterman en Hanekamp stellen meer expliciet voor om 'de waarde van een statistisch leven op 6 miljoen euro vast te stellen [en om] uitgaande van een levensverwachting van 80 jaar [een] maximale investering voor een qaly van 75.000 euro' als norm te stellen. ${ }^{12}$ In een later onderzoek naar kosteneffectiviteit van interventies negeert het RIVM deze voorstellen en stelt:

'Het begrip "kosteneffectief"' is een normatief begrip en suggereert dat er heldere afkappunten bestaan om een gezondheidsinterventie als kosteneffectief of niet kosteneffectief te bestempelen. Wat als kosteneffectief wordt gezien hangt vanzelfsprekend samen met het welvaartsniveau van een land en zal dus ook van land tot land verschillen. In sommige landen wordt een interventie kosteneffectief genoemd als deze minder kost dan $€ 50.000$ per QALY en soms ligt de grens veel lager, bijvoorbeeld op $€ 20.000$ per QALY. Dit afkappunt wordt in Nederland regelmatig genoemd als acceptabel in de context van kosteneffectiviteit van [medische] preventie'. ${ }^{13}$

Nut en noodzaak van het beoordelen van de doelmatigheid van overheidsinterventies is dus algemeen aanvaard. Het belang van een beoordeling van de doelmatigheid van het overheidsbeleid in reactie op de COVID-19-pandemie kan moeilijk overschat worden. Sinds het virus ontsnapt is uit ground-zero in Wuhan (China) waart het rond over de gehele wereld. De komende jaren staat ieder mens continu bloot aan besmetting met het virus. Dat beschermend beleid nodig is, staat niet ter discussie. Wel is het de vraag welk beleid het meest kosteneffectief is.

De vraag stellen of een lockdown wel de meest doelmatige, kosteneffectieve aanpak is om ten tijde van een pandemie de volksgezondheid te bevorderen, is voor velen contra-intuïtief. Ter toelichting - en verdediging - is het daarom belangrijk enkele zaken vooraf zo duidelijk mogelijk te maken. Een eerste punt is dat, zoals hiervoor duidelijk gemaakt, vragen over doelmatigheid bij overheidsinterventies vast onderdeel van besluitvormingsprocessen zijn. Een tweede punt is dat het bij het stellen en beantwoorden van zulke vragen niet gaat om een tegenstelling tussen gezondheid en economie. De analyse vindt plaats door vergelijkingen te maken in termen van gewonnen of verloren qaly's. Ten derde kunnen we opmerken dat het impliciete ethische doel van een KBA 'het grootste goed voor het grootste aantal' is. Hoewel niet expliciet of noodzakelijk is de impliciete normatieve aanname achter een KBA dat meer qaly's genereren in beginsel beter is dan met minder genoegen nemen. Wie in een specifieke situatie met minder genoegen wil nemen, heeft als de keuze expliciet gemaakt moet worden iets uit te leggen. 


\section{Hoeveel qaly's heeft het beleid opgeleverd?}

De omvang van de gezondheidsschade die COVID-19 zou aanrichten en de mate waarin deze door maatregelen te voorkomen is, moet geschat worden. In alle beschouwingen hierover staat de kans op overlijden voorop. Het meten van het succes van pogingen gezondheidsschade te voorkomen, komt dan neer op het beantwoorden van de vraag 'hoeveel mensen zijn niet overleden?'. Inzicht geven in wat niet gebeurd is maar wel had kunnen gebeuren, is notoir moeilijk.

Zulke berekeningen worden gemaakt met modellen waarin tal van factoren onzeker zijn. Cruciaal zijn de verwachte aantallen besmettingen en de verwachte kans dat besmette mensen zullen overlijden. Men is daarom aangewezen op aannames. Ioannidis merkt in dit verband het volgende op:

'Proponents of "lockdown to flatten the curve" should acknowledge that [the lockdown] gains time for hospital preparedness but that most, if not all, covid-19 deaths will still happen when measures are relaxed - unless effective treatments and/or vaccines emerge. Moreover, the lockdown-to-flatten-thecurve rationale ignores seasonality and espouses 100 year old observational data from a 1918 pandemic with [a mortality] rate 100 times higher than covid-19'. ${ }^{14}$

Ioannidis wijst al vroeg op het belang van de wetenschappelijke onzekerheid bij de vraag welk beleid gewenst was. Hij vraagt zich af of sprake is van 'A fiasco in the making?' ${ }^{15}$ Laten we eerst, omdat daarover meer met enige zekerheid te zeggen valt, kijken naar de (over)sterfte in het voorjaar van 2020.

Medisch Contact haalt Ioannidis op 1 april aan door erop te wijzen dat de (voorlopig!) best beschikbare studies aangeven dat de kans op overlijden voor COVID-19 tussen $0,1 \%$ en $0,9 \%$ ligt. ${ }^{16}$ Later internationaal vergelijkend onderzoek van hem bevestigt deze schatting voor de bevolking als geheel. Voor mensen jonger dan zeventig jaar blijkt de sterftekans nog veel kleiner te zijn en te liggen tussen $0,00 \%$ en $0,23 \%$ met een mediaan van $0,04 \% .{ }^{17}$ Begin september lieten Goldstein en Lee zien dat in veel landen de overlijdenscurve naar leeftijd voor COVID-19 vrijwel gelijk is aan de overlijdenscurve voor alle oorzaken. ${ }^{18}$ Het zijn dus inderdaad bij uitstek ouderen die kans hebben op overlijden bij besmetting met COVID-19.

Omdat sterfte gerelateerd aan (primaire) doodsoorzaak wordt geregistreerd, lijkt de (over)sterfte in verband met COVID-19 gemakkelijker bij te houden. Maar in de dagelijkse rapportages over het aantal doden met een positieve COVID-19-test ging het wekenlang uitsluitend over overlijden in ziekenhuizen, want daar lagen de mensen met een positieve test. We hadden het CBS nodig om ons te vertellen 
dat bijna de helft van de sterfte in verpleeghuizen plaatsvond en dat daarbij in de meeste gevallen ook een COVID-19-besmetting in het geding was. ${ }^{19}$ Het RIVM meldt in het najaar:

'In de winter van 2019/2020 was de influenza-epidemie kort en mild (week 5 tot en met 7 2020). De oversterfte was in deze periode met 404 veel lager dan de gemiddelde oversterfte in de afgelopen 5 griepepidemieën (6.443). Een korte opleving van de griepepidemie in week 10 en11 2020 overlapte met de eerste 2 weken van de COVID-19 epidemie. De oversterfte in week 10 tot en met 19 van de COVID-19 epidemie was $9.768^{\prime} .{ }^{20}$

Het overlijden van bijna 10.000 mensen meer dan gebruikelijk is indrukwekkend. We moeten dit cijfer echter wel in perspectief plaatsen. Merk op dat de oversterfte bij griepepidemieën jaarlijks gemiddeld bijna 6500 is. Maar de griepepidemie die begin 2018 bijna vijftien weken duurde, bracht een oversterfte van 9444 met zich mee die bijna net zo groot is als die bij COVID-19. Dat er in maart en april van 2020 meer mensen dan verwacht overlijden, duurt van week 12 tot week 19. Daarna blijft het overlijden binnen de boven- en ondergrens van de verwachting op een niveau iets onder de gemiddelde verwachting. Alleen in de zeer warme week 33 tijdens de zomer van 2020 is er weer even sprake van oversterfte.

Al deze informatie over een kennelijk niet uitzonderlijk hoge mate van oversterfte roept de vraag op hoeveel mensenlevens er daadwerkelijk gered zijn door het beleid. Ik vond niet veel onderzoeken die antwoord geven op deze vraag. NRC Handelsblad haalt al vroeg in de lockdown op 16 april de schatting aan die gezondheidseconomen Stadhouders en Koolman gemaakt hebben. Zij schatten dat de lockdown een gezondheidswinst van $€ 15$ tot 75 miljard oplevert. Hun model rekent ver in de tijd door tot het moment dat tien miljoen mensen besmet zijn en groepsimmuniteit bereikt is. Zij gaan ervan uit dat de sterftekans ligt tussen $0,4 \%$ en $2,0 \%$. Een cruciaal aspect van hun analyse - en van vergelijkbare analyses van anderen - is dat zij ervan uitgaan dat 'geen lockdown' ook betekent 'helemaal geen beleid' en tevens 'geen gedragsaanpassingen van burgers'. Helaas ontbreekt in het artikel in NRC Handelsblad informatie over de gemiddelde waarde van een qaly waarmee zij gerekend hebben, zodat het aantal 'gewonnen qaly's' niet duidelijk wordt. Hun originele berekeningen heb ik niet kunnen vinden.

Gelet op de lage sterftekans die Ioannidis noemt, is de laagste waarde van 0,4\% in de scenario's van Stadhouders en Koolman waarschijnlijk te hoog. Dat geldt dan ook voor hun laagste schatting van de behaalde gezondheidswinst van $€ 15$ miljard. Iets meer dan een maand later meldt onderzoeksbureau Gupta Strategists: 'Ziekenhuiszorg voor COVID-patiënten heeft in Nederland naar schatting 13 duizend tot 21 duizend gezonde levensjaren (QALY's) gered (in maart en april)'. ${ }^{21}$ Gaan we uit van deze schatting van gewonnen qaly's, dan komen we uit op een veel lagere gezondheidswinst in euro's dan die van Stadhouders en Koolman. Die 
varieert van bijna $€ 150$ miljoen [13.000 $\mathrm{x} € 11.500 /$ qaly] tot $€ 1,7$ miljard [21.000 $€ € 80.000 /$ qaly]. Dat is een factor tien tot honderd kleiner dan zelfs de lage schatting van Stadhouders en Koolman. Een maand na de studie van Gupta zegt Koolman in een interview: 'Flattening the curve is eigenlijk deepening the crisis' ${ }^{22}$ Hij lijkt daarmee zelf te erkennen dat zijn oorspronkelijke schattingen (veel) te hoog waren.

Begin juni 2020 kopt BBC News: 'Coronavirus: Lockdowns in Europe saved millions of lives'. ${ }^{23}$ Een studie van de onderzoeksgroep van Imperial College London, de groep die leidend is in het adviseren van de Britse regering, schat dat in elf Europese landen 3,1 miljoen doden minder zijn gevallen door de maatregelen. ${ }^{24}$

Trouw doet een dag na de BBC verslag van dit onderzoek. Zij citeren de Utrechtse hoogleraar theoretische epidemiologie Heesterbeek. Volgens hem moeten

'de aantallen met een flinke schep zout worden genomen. “Zo'n berekening is puur hypothetisch. Alsof het leventje tijdens de pandemie gewoon zijn gangetje zou blijven gaan en we aan het eind van het jaar zouden constateren: goh, er zijn miljoenen mensen aan het virus overleden. Ook zonder lockdown zouden mensen hun gedrag hebben aangepast. Bovendien was het model helemaal niet voor deze berekening gemaakt"'. ${ }^{25}$

De krant kopt dan ook terecht dat het aantal geredde levens lastig te berekenen is. Dat geldt des te meer voor qaly's, omdat dan ook het voor de geredde mensen resterende aantal levensjaren en de kwaliteit ervan geschat zou moeten worden. Wat dit laatste betreft, Stadhouders en Koolman namen aan dat per gered leven gemiddeld sprake zou zijn van drie qaly's.

Het is goed om te bedenken dat 'een leven redden' bij COVID-19 van kortstondige waarde is. Het gaat immers niet om een drenkeling redden of door reanimatie voorkomen dat iemand aan een hartstilstand overlijdt. Wie zo verzwakt is dat een besmetting met COVID-19 fataal kan zijn, moet iedere dag opnieuw 'gered' worden. Dit impliceert dat alle geredde levens als voorlopig moeten worden aangemerkt. Dat maakt het lastig om te verantwoorden dat je een dergelijk gered leven, zoals Stadhouders en Koolman doen, op drie qaly waardeert. Zo bezien is ook de laagste schatting van Gupta, 13.000 qaly's, mijns inziens nog aan de hoge kant. Om dit punt op scherp te stellen: nul lijkt mij zelfs verdedigbaar, omdat degene die vandaag gered lijkt heel goed morgen alsnog slachtoffer kan zijn.

Ik rond deze kwestie af met nog een laatste relativering: het feit dat er voor zover het zich midden oktober laat aanzien nog geen sprake is van oversterfte. De gezondheidswinst van de maatregelen om de tweede golf te beteugelen lijken daarmee voor wat betreft gewonnen qaly's nog onzekerder dan bij de eerste golf. De definitie van epidemie spreekt van 'een ongebruikelijke mate van voorkomen' van een ziekte. Technisch gezien geldt dan voor een nieuwe ziekte dat er bij één 
patiënt al van een epidemie gesproken kan worden. Maar wanneer is bij zo'n nieuwe ziekte de epidemie of pandemie nu voorbij? Nemen we oversterfte als criterium, dan is de pandemie 'over' sinds week 20 van dit jaar. Dat lijkt mij, gelet op het idee dat optimale volksgezondheid het streven zou moeten zijn, geen onaannemelijke opvatting.

\section{De opportuniteitskosten van het pandemiebeleid}

Wie inzicht wil krijgen in de opportuniteitskosten van het pandemiebeleid, is eveneens aangewezen op rekenmodellen en aannames. Een belangrijk verschil lijkt wel dat economische kosten meer een intersubjectief vast te stellen aard hebben dan het aantal niet-overleden mensen. Desalniettemin heerst hier ook onzekerheid. Hieronder is de aanname dat groei van de staatsschuld bij benadering overeenkomt met de economische schade van het beleid. Om nu niet de fout te maken, zoals bij het schatten van geredde levens gebeurt, te denken dat het (economisch) leven zonder beleid gewoon zijn gang zou gaan, kunnen we een percentage van dit bedrag aftrekken. Dit percentage geldt dan als de economische schade die door de ziektelast van het virus en door de gedragsaanpassingen van mensen hierop sowieso zou zijn ontstaan. Aanhangers van het gevoerde beleid zullen dat percentage allicht hoger inschatten dan critici.

Helsloot stelt over de kosten al direct als in maart de eerste beperkende maatregelen worden afgekondigd: 'We hebben [een] noodpakket van 80 miljard euro, geld dat we ook in de Nederlandse gezondheidszorg hadden kunnen steken. Met dat geld hadden we 1 miljoen levensjaren kunnen winnen'. ${ }^{26}$ Bij Jort Kelder in zijn tv-programma zegt hij dat het overheidsbeleid als feitelijk beleidsdoel heeft te voorkomen dat de capaciteit van ic-afdelingen te klein wordt. Door uitbreiding van de capaciteit wordt dit voorkomen en dit zou naar zijn mening ongeveer 1000 qaly's kunnen opleveren. ${ }^{27}$ Helsloot gaat er hierbij van uit dat bij de 'geredde' mensenlevens gemiddeld sprake is van één qaly. Hij stelt dan ook dat, zo gerekend, de opportuniteitskosten een factor duizend hoger zijn. Er worden volgens hem immers niet een miljoen maar slechts duizend qaly's gered.

Het is niet moeilijk om aannemelijk te maken dat de verhouding nog slechter is. Zo hanteert Helsloot de maximumprijs van $€ 80.000$ die verantwoord wordt geacht voor een gewonnen qaly. De gemiddelde prijs voor een gewonnen qaly ligt in de reguliere gezondheidszorg met $€ 11.500$ echter lager. ${ }^{28}$ Nemen we dat bedrag als maatstaf, dan is de gezondheidsschade van de lockdown ongeveer zeven miljoen verloren qaly's en het middel dus 7000 keer erger dan de kwaal. Nemen we niet de schatting van Helsloot - 1000 gewonnen qaly's - maar het maximaal aantal van 21.000 gewonnen qaly's dat Gupta inschat ${ }^{29}$, dan is het middel 'slechts' 333 keer erger dan de kwaal. Aannames spelen dus een zeer grote rol, maar de uitkomst is steeds uiterst negatief. 
De staatsschuld zal bovendien naar verwachting met aanmerkelijk meer dan $€ 80$ miljard groeien: 'De economische schade door de corona-uitbraak zorgt voor een ongekende verslechtering van de overheidsfinanciën. (...) De staatsschuld zal dit jaar vermoedelijk stijgen (...) van een kleine 400 miljard eind vorig jaar naar ruim 500 miljard'. ${ }^{30}$ De economische schade van de Nederlandse maatregelen ter beperking van de COVID-19-pandemie wordt daarmee vijf weken na 17 maart op ruim $€ 100$ miljard geraamd. Daarbovenop komen dan nog de noodprogramma's die de EU optuigt. Het nieuwe noodfonds van 750 miljard zal voor een belangrijk deel bestaan uit schenkingen van 'rijke' landen als Nederland en Duitsland aan 'zwaar getroffen' landen als Italië en Spanje. De $€ 80$ miljard waar Helsloot mee rekent, is hoogstwaarschijnlijk een te laag bedrag.

De economische malaise is een mondiaal verschijnsel. Dit maakt het vooruitzicht van een moeilijke en langdurige herstelperiode waarschijnlijk. 'Tekorten en schulden exploderen wereldwijd' kopt NRC Handelsblad. ${ }^{31}$ Het IMF aanhalend meldt de krant:

'Veel, zo niet alles, komt in deze crisis aan op de zogenoemde fiscal response: de mate waarin overheden hun portemonnee trekken om uitvallende delen van de economie overeind te houden. Primair gaat het dan om levens redden. Daarvoor, zo raamt het IMF, is wereldwijd in elk geval 3.300 miljard dollar nodig aan directe steun voor zorg en vraaguitval in de economie. Daar komt nog eens 4.500 miljard dollar aan leningen, kapitaalinjecties en garanties bij'. ${ }^{32}$

Twee maanden later meldt de Wereldbank: 'The pandemic is expected to plunge most countries into recession in 2020 , with per capita income contracting in the largest fraction of countries globally since 1870'. ${ }^{33}$

De Nederlandsche Bank (DNB) stelt op dat moment: 'In de raming voor 2020 daalt het bruto binnenlands product in Nederland met $6,4 \%$, bijna twee keer zo hard als tijdens de kredietcrisis in 2009.' DNB verwacht overigens wel dat economisch herstel vanaf '[h] alverwege 2020 [in]treedt'. Wel wordt hierbij voorzichtigheidshalve opgemerkt: 'Omdat de onzekerheden rond de raming groter zijn dan gebruikelijk, is naast de raming ook een mild en een zwaar scenario opgesteld.' Over de werkloosheid is DNB ronduit pessimistisch: 'De werkgelegenheid neemt flink af in 2020 en 2021. Daardoor gaat de werkloosheid dit jaar omhoog naar $4,6 \%$ van de beroepsbevolking en stijgt deze volgend jaar verder naar $7,3 \%$. In 2022 volgt weer een daling naar 5,7\%,34 Werkloze mensen lopen meer gezondheidsrisico dan werkenden. Op deze factor ga ik in een volgende paragraaf apart in. 
Kortom, de economische schade die het pandemiebeleid aanricht, is extreem groot. De financiële kosten zijn torenhoog en deze enorme bedragen zijn daarmee niet beschikbaar voor andere uitgaven. Door deze bedragen om te zetten in gemiste kansen om met investeringen in de gezondheidszorg qaly's te genereren, krijgen we inzicht in de gezondheidsschade van het beleid. We moeten, als eerder opgemerkt, wel bedenken dat ook minder vergaande maatregelen economische schade aangericht zouden hebben. Door het virus veroorzaakte ziekte zou daarnaast natuurlijk ook voor economische en gezondheidsschade zorgen. Deze schade moeten we aftrekken van de totale economische schade. Alleen het verschil betreft de opportuniteitskosten van het beleid.

Het is bovendien zeker dat een deel van de uitgaven wel degelijk rechtstreeks naar de gezondheidszorg vloeit. Vanwege COVID-19 was bijvoorbeeld uitbreiding van ic-afdelingen nodig. En ook de ontwikkeling van vaccins vergt extra investeringen. Schatten we de 'onvermijdelijke schade' en de directe investeringen in de gezondheidszorg op 50\%? Dan is het door geschatte opportuniteitskosten veroorzaakte verlies aan qaly's nog steeds extreem groot. We delen dan $€ 50$ miljard door $€ 11.500$ en door $€ 80.000$ per qaly. De gezondheidsschade kan dan geschat worden tussen ruim 600.000 en ruim 4.000.000 qaly's.

\section{De gezondheidsschade van uitgestelde zorg}

Het werd in het voorjaar van 2020 al snel duidelijk dat met de toevloed van COVID-19-patiënten de ziekenhuizen hun reguliere planbare zorg zouden moeten afschalen. Zorgen bestonden vooral over het uitstellen van operaties en andere behandelingen bij mensen met hart- en vaatziekten en kanker. Later werd ook duidelijk dat mensen zich met hun andere gezondheidsklachten veel minder bij hun huisarts en daarmee ook bij de specialistische zorg meldden. Al dit uitstel brengt in directe zin gezondheidsschade teweeg. Hieraan werd in de serieuze landelijke dagbladen ook in het voorjaar al wel enige aandacht besteed. Het duurt echter tot 9 oktober voordat NRC Handelsblad een interview met een internist plaatst onder de confronterende kop 'Waarom laten we patiënten met andere ziekten overlijden?'. ${ }^{35}$ De vraag is hoe het daarbij opgelopen verlies aan qaly's zich verhoudt tot de door het beleid geredde qaly's.

Het eerder kort geciteerde rapport van Gupta Strategists geeft schattingen van de gezondheidsschade van uitgestelde zorg. De titel van het bericht op de website belooft niet veel goeds: 'Het koekoeksjong dat COVID heet'. ${ }^{36}$ Hieronder de volledige samenvattende tekst:

'Ziekenhuiszorg voor COVID-patiënten heeft in Nederland naar schatting 13 duizend tot 21 duizend gezonde levensjaren (QALY's) gered (in maart en april). Echter, deze winst ging gepaard met een onacceptabel verlies in de reguliere zorg. Terwijl COVID-zorg de ziekenhuizen overspoelde, liep juist de 
reguliere zorg ongekende, disproportionele schade op. Het stopzetten van de reguliere zorg leidde tot een verlies van naar schatting 100 duizend tot 400 duizend levensjaren. Daarmee is het verlies in de reguliere zorg ongeveer tien keer zo hoog als zowel het aantal gezonde levensjaren gewonnen met COVIDzorg als het aantal gezonde levensjaren verloren door COVID'. ${ }^{37}$

De website ZorgDomein bevestigt de enorme achterstand in reguliere zorg die is opgetreden:

'Na de bekende "crash" van half maart zagen we het verwijsvolume naar nagenoeg alle zorgmarkten met gemiddeld $75 \%$ dalen ten opzichte van dezelfde week in 2020. Dat beeld bleef drie weken redelijk stabiel. Vanaf de vierde week zagen we weer langzaamaan het aantal verwijzingen herstellen naar gemiddeld $50 \%$ minder verwijzingen naar alle zorgmarkten ten opzichte van dezelfde periode vorige jaar.'

Dit heeft geleid tot een 'Stuwmeer aan uitgestelde verwijzingen opgelopen naar 1 miljoen verwijzingen in totaal'. Om dit 'stuwmeer' weg te werken, zijn aangepaste criteria nodig om de urgentie te bepalen. ZorgDomein meldt dat de Nederlandse Zorgautoriteit (NZA) Gupta Strategists een nieuwe 'Urgentielijst medisch-specialistische zorg' heeft laten opstellen. ${ }^{38}$

Andere schattingen heb ik niet kunnen vinden en natuurlijk zijn er bedenkingen te uiten bij de aannames die door Gupta gedaan zijn. Desalniettemin is het resultaat veelzeggend. Nemen we de gemiddelden van beide schattingen, dan staan tegenover 17.000 gewonnen qaly's 250.000 verloren qaly's. Alleen kijkend naar deze directe vergelijking van verloren en gewonnen qaly's zien we, net als bij de opportuniteitskosten, dat het middel erger is dan de kwaal. De verschillen zijn in deze vergelijking wel minder extreem dan bij de opportuniteitskosten. Vergelijken we beide minimum- met beide maximumschattingen dan is het middel minimaal ongeveer vijf keer en maximaal ongeveer dertig keer erger dan de kwaal.

\section{De gezondheidsschade van werkloos zijn}

Hierboven werd DNB aangehaald over de verwachte ontwikkeling van de werkgelegenheid. In 2020 zou de werkloosheid oplopen tot 4,6\% van de beroepsbevolking en deze stijging zou in 2021 kunnen doorlopen naar 7,3\%. Dat daarna in 2022 een daling verwacht wordt naar 5,7\% betekent echter nog steeds dat het (veel?) meer dan twee jaar zal duren om op het niveau van maart 2020 terug te komen. De relevante cijfers van het CBS doen vermoeden dat sprake is van een onderschatting. Per 17 september wordt voor de maand augustus al het percentage van 4,6\% gemeld. Ter vergelijking: in augustus 2019 is sprake van $3,5 \%$ en in maart 2020 van 2,9\%. De dalende trend is dus radicaal omgeslagen. In 
aantallen is de toename sinds maart 2020 er een van 273.000 naar $426.000 .{ }^{39}$ Een verdere stijging met nog eens bijna 3\% naar de geschatte 7,3\% voor $2021 \mathrm{zal}$ hier nog bijna 300.000 werklozen aan toevoegen. Ruim 400.000 mensen worden dus waarschijnlijk werkloos als gevolg van de coronacrisis en velen daarvan zullen dat in ieder geval enkele jaren ook blijven. Voor de goede orde: dit valt niet geheel aan het beleid toe te schrijven. Ook het COVID-19-virus zelf zou door het veroorzaken van overlijden, ziekte en gedragsaanpassingen voor economische schade hebben gezorgd.

Werkloos zijn is slecht voor je gezondheid. Website Huffpost kopt dit letterlijk in 2013: 'Unemployment Is Bad for Your Health'. In het artikel wordt gewezen op een Finse studie die onder andere vaststelt: 'Rates of mortality for previouslyunemployed people were higher for men (141 percent) than for women (35 percent).' Ook wordt gewezen op een onderzoek in het Verenigd Koninkrijk waaruit blijkt dat 'unemployment was strongly linked to increased long-term mortality. In this study, researchers tried to statistically control for other pre-existing risk factors, such as age, weight, smoking, excess drinking, social class, and other factors. Still, the increased risk was 47 percent'. ${ }^{40}$

Ik vond geen specifieke informatie over door aan COVID-19 gerelateerde werkloosheid verloren levens of qaly's in Nederland. Wel vond ik een rapport hierover opgesteld door Public Health Wales onder de titel: 'Unemployment due to Coronavirus and Longstanding Illnesses'. Hierin wordt aangegeven dat 'the proportion of the population suffering from longstanding illnesses could increase by around four per cent over the next three years'. Daarnaast verwacht men dat ook 'the percentage of adults living with limiting longstanding illnesses' zal stijgen. Dat geldt ook voor het percentage 'adults with chronic health conditions'. ${ }^{41}$

In de medische literatuur is een verhoogd langetermijnrisico op overlijden voor werklozen onomstreden. Wel zijn de uitkomsten vanzelfsprekend contextgevoelig. De algemene welvaart, de hoogte van uitkeringen, alsmede de beschikbaarheid van goede - ook psychologische - gezondheidszorg zijn alle belangrijk. Ik zal hier dus niet zelf een berekening proberen te maken, maar geef nog twee citaten uit de medische literatuur over twee andere economisch ontwikkelde landen. Allereerst de conclusie van een systematische review en meta-analyse van onderzoek in de Verenigde Staten. Vervolgens de bevindingen van een onderzoek in Zweden.

Roelfs en anderen noemen in 2011 als 'highlights' van hun systematische review en meta-analyse van relevant onderzoek in de VS:

- $\quad$ The risk of death for unemployed persons was $63 \%$ higher than the risk of death for employed persons.

- The relative mortality risk associated with unemployment was $37 \%$ higher for men than for women.

- The relative mortality risk associated with unemployment was significantly lower for workers approaching retirement age (50-65 years of age). 
- The relative mortality risk associated with unemployment remained elevated among studies with lengthy follow-up periods, suggesting that becoming unemployed induces a long-term change in the underlying mortality risk.' . ${ }^{42}$

De Zweedse studie van Norström en anderen uit 2019 wijst in dezelfde richting:

'In our study, we show that the health deterioration from unemployment is likely to be large, as our estimated effect implies an almost $10 \%$ worse health (in absolute terms) from being unemployed compared to being employed. This further highlights that unemployment is a public health problem that needs more focus'. ${ }^{43}$

Het blijkt echter dat de relatie tussen werkloosheid en overlijden op macroniveau niet altijd duidelijk terug te vinden is in het sterftecijfer van een samenleving. Trouw meldt in 2019:

'Tot nu toe was niet duidelijk wat de samenhang is tussen de economische cyclus en sterftecijfers. Sommige economen zien de sterftecijfers dalen als het in een land economisch goed gaat, andere economen zien juist het omgekeerde'. ${ }^{44}$

Dat individuele werklozen een groter risico op vroegtijdig overlijden hebben, lijkt moeilijk te rijmen met de bevinding dat economische recessie en dus meer werklozen samenhangt met lagere sterftecijfers.

Alles overziend waag ik mij voor dit aspect niet aan een schatting - zelfs niet een ruwe schatting - van het verlies aan qaly's in relatie tot werkloosheid. In algemene zin lijkt het mij echter wel verantwoord om te veronderstellen dat mensen die de komende tijd in groten getale werkloos raken, te maken zullen krijgen met extra ziektelast zoals het rapport voor Wales aangeeft.

\section{Onzekerheden en mogelijke andere factoren}

Voor ik tot een afrondende conclusie kom, sta ik eerst nog even stil bij mitsen en maren die bij een analyse als deze met recht naar voren kunnen worden gebracht. In een kosten-batenanalyse kunnen alle relevant geachte factoren ingebracht worden. Daarbij is ook altijd sprake van aannames en schattingen, omdat ondubbelzinnige gegevens zelden of nooit beschikbaar zijn. Ik heb hiervoor geprobeerd antwoord te geven op vier vragen. Veel is daardoor onbesproken gebleven. De vraag is dus of dat wat niet meegenomen is het totaalbeeld in belangrijke mate anders zou maken. Ik meen van niet en licht dat hieronder toe. 
Voor de batenkant van de analyse moet er inzicht zijn in de gezondheidswinst van het beleid. Daarbij is de aandacht bij uitstek uitgegaan naar het vergroten van de ic-capaciteit, zodat daar geen mensen geweigerd zouden hoeven worden. Zijn er dan geen andere factoren te bedenken die gezondheidswinst kunnen opleveren? Ik ben eigenlijk alleen het idee van minder verkeersdoden door minder (auto)mobiliteit tegengekomen. Wellicht kunnen we daarnaast ook denken aan minder uitstoot van gezondheidsbedreigende stoffen door auto's en industrie. Alleen voor de verkeersdoden vond ik een bericht en daaruit blijkt niet dat minder verkeer tot minder doden geleid heeft. ${ }^{45}$ Dat minder verkeer niet lijdt tot minder doden betekent ook dat er niet minder donororganen beschikbaar zijn gekomen. Maar het reserveren van ic-capaciteit voor covidpatiënten betekent mogelijk wel dat er minder transplantaties zijn uitgevoerd. Een kosten-batenanalyse van de gezondheidseffecten van minder autokilometers is dus een complexe aangelegenheid. Ik durf niets te zeggen over het aantal qaly's aan de kant van de baten of de kosten. Dat het om aantallen gaat die het geschetste beeld serieus veranderen, lijkt mij zeer onwaarschijnlijk.

Relativerende opmerkingen over de berekening van opportuniteitskosten heb ik bij de bespreking ervan al gemaakt. Ik heb daaraan niets meer toe te voegen.

Naast de kostenpost van het uitstellen van reguliere zorg komen we ook wel andere factoren tegen die als schadelijke effecten van de lockdown worden genoemd. Denk bijvoorbeeld aan toegenomen risico's van huiselijk geweld, toegenomen stress vanwege thuiswerken of de dreiging van baanverlies of toegenomen armoede door economische achteruitgang. Dat laatste is in Nederland van minder belang dan in arme landen. Maar in arme landen ligt dat wezenlijk anders en het lijkt goed dit toch ook even expliciet te benoemen. Het World Food Program (WFP) meldt al in april dat het aantal mensen dat acute honger lijdt in 2020 waarschijnlijk verdubbelt van 165 miljoen naar 325 miljoen. ${ }^{46}$ In zijn bericht over 'Food security and Covid-19' meldt ook de Wereldbank: 'As the coronavirus crisis unfolds, disruptions in domestic food supply chains and other shocks affecting food production, and loss of incomes and remittances are creating strong tensions and food security risks in many countries'. ${ }^{47}$

Voor wat betreft de werkgerelateerde stress als negatieve invloed zijn er natuurlijk ook werknemers die voordelen van thuiswerken ondervinden. Dat huiselijk geweld ook in Nederland toegenomen is, lijkt aannemelijk. Onzekerheid geeft stress en achter de voordeur opgesloten zijn, biedt meer mogelijkheden aan (potentiële) daders dan in normale omstandigheden. Ik ben geen schattingen tegengekomen, maar ook in dit geval vermoed ik dat de hierdoor verloren qaly's het geschetste beeld niet wezenlijk veranderen. Dat de coronapandemie een emotionele tol eist van de bevolking wordt ook steeds duidelijker, al blijft onduidelijk in welke mate dit door het virus of door het beleid wordt veroorzaakt. ${ }^{48}$ 
Als het gaat om de effecten van werkloosheid heb ik behalve de zojuist gemaakte opmerking over de gevolgen van armoede en honger in arme landen niets toe te voegen aan wat in die paragraaf besproken is.

Bij het volgen van het nieuws en het bespreken van ontwikkelingen en ideeën met anderen heb ik geen andere factoren gehoord of kunnen bedenken die van (belangrijke) invloed zouden kunnen zijn. Maar zoals hiervoor gezegd: wie ze wel kent, kan ze gebruiken om het door mij geschetste beeld aan te passen. Een kosten-batenanalyse is gelukkig principieel open voor het meenemen van alle relevante factoren.

\section{Conclusie}

Alles overziend kan de conclusie van mijn kosten-batenanalyse kort en duidelijk zijn. Het beleid heeft meer qaly's gekost en zal nog meer qaly's kosten dan er zijn gewonnen. Wanneer we ons beperken tot een vergelijking van de gewonnen qaly's met de verloren qaly's door uitgestelde zorg is, zoals gezegd, het middel al ongeveer vijf keer tot dertig keer erger dan de kwaal. Wie zich realiseert dat 'geredde levens' niet eenmalig is, maar langdurige, continue inspanning vereist, zal het aannemelijk vinden dat de schevere verhouding meer waarschijnlijk is. Voegen we daaraan de op korte termijn te verwachten groeiende ziektelast en de op lange termijn verhoogde sterftekans als gevolg van werkloosheid toe, dan wordt het beeld in niet onaanzienlijke mate negatiever. Voor wie met mij van mening is dat ook opportuniteitskosten meegewogen moeten worden - in welke mate dan ook komt onvermijdelijk uit bij een schrikbarend negatieve balans.

\section{Referenties}

\section{Wetenschappelijke bronnen}

Flaxman, S. e.a., 'Estimating the effects of non-pharmaceutical interventions on COVID-19 in Europe', Nature 2020; doi: 10.1038/s41586-020-2405-7.

Goldstein, J.R. \& R.D. Lee, 'Demographic perspectives on the mortality of COVID-19 and other epidemics', in: PNAS September 8, 2020-117(36), p. 22035-22041; first published August 20, 2020; doi: 10.1073/pnas.2006392117.

Helsloot, I., R. Pieterman \& J.C. Hanekamp, Risico's en redelijkheid. Verkenning van een rijksbreed beoordelingskader voor de toelaatbaarheid van risico's, Den Haag: Boom Juridische uitgevers 2010.

Hsiang, S. e.a., 'The effect of large-scale anti-contagion policies on the COVID-19 pandemic', Nature 2020; doi: 10.1038/s41586-020-2404-8.

Ioannidis J. e.a., 'COVID-19 Antibody Seroprevalence in Santa Clara County, California', MedRxiv preprint (27 april 2020); doi: 10.1101/2020.04.14.20062463.

Ioannisis, J., 'Should governments continue lockdown to slow the spread of covid-19?', BMJ 2020;369:m1924, 3 juni 2020; doi: 10.1136/bmj.m1924.

Ioannidis, J., 'The infection fatality rate of COVID-19 inferred from seroprevalence data', MedRxiv preprint (8 juni 2020); doi: 10.1101/2020.05.13.20101253. 
Konings, M. \& M. Lindeboom, 'Volksgezondheid en economische neergang: De associatie tussen toenemende werkloosheid en sterfte in Nederland', TPEdigitaal, 2018-12(1), p. 39-56.

Norström, F. e.a., 'Does unemployment contribute to poorer health-related quality of life among Swedish adults?', Public Health 2019-19, p. 457; doi: 10.1186/ s12889-019-6825-y.

Roelfs, D.J. e.a., 'Losing life and livelihood: A systematic review and meta-analysis of unemployment and all-cause mortality', Social Science \& Medicine, 2011-72(6), p. 840-854; doi: 10.1016/j.socscimed.2011.01.005.

\section{Internetbronnen}

BBC 8 juni 2020, 'Coronavirus: Lockdowns in Europe saved millions of lives', www.bbc.com/news/health-52968523, geraadpleegd op 9 juni 2020.

BBC 6 oktober 2020, 'Coronavirus: Europe experiencing pandemic fatigue', www.bbc.com/ news/health-54417547, geraadpleegd op 9 oktober 2020.

CBS 16 november 2019, 'Doden en gewonden in het wegverkeer', www.cbs.nl/nl-nl/ nieuws/2019/16/11-procent-meer-verkeersdoden-in-2018, geraadpleegd op 9 oktober 2020.

CBS 17 juni 2020, 'Hoeveel sterfgevallen zijn er per week?', www.cbs.nl/nl-nl/faq/corona/ medisch/hoeveel-sterfgevallen-zijn-er-per-week, geraadpleegd op 9 oktober 2020.

CBS 13 juni 2020, 'Wat zijn de economische gevolgen van corona?', www.cbs.nl/nl-nl/ dossier/cbs-cijfers-coronacrisis/wat-zijn-de-economische-gevolgen-van-corona, geraadpleegd op 19 juni 2020.

CBS 28 mei 2020, 'Sterfte in Coronatijd', www.cbs.nl/nl-nl/nieuws/2020/22/sterfte-incoronatijd, geraadpleegd op 8 juni 2020.

CBS 17 september 2020, 'Arbeidsdeelname en werkloosheid per maand', www.cbs.nl/nl-nl/ cijfers/detail/80590ned, geraadpleegd op 9 oktober 2020.

CPB 18 maart 2015, Doelmatigheid in de curatieve zorg', www.cpb.nl/publicatie/ doelmatigheid-in-de-curatieve-zorg, geraadpleegd op 9 oktober 2020.

de Volkskrant 21 mei 2020, Ellen de Visser, 'De andere rekening van de coronazorg: "Door uitgestelde zorg gingen 100 tot 400 duizend levensjaren verloren"', www.volkskrant.nl/wetenschap/de-andere-rekening-van-de-coronazorg-dooruitgestelde-zorg-gingen-100-tot-400-duizend-levensjaren-verloren $\sim$ bd73a0d5, geraadpleegd op 13 juni 2020.

de Volkskrant 19 juni 2020, 'Strijd tegen corona doet economie onnodig pijn', https:// volkskrant.e-pages.pub/titles/volkskrant/7929/publications/978/pages/2, geraadpleegd op 19 juni 2020.

DNB 8 juni 2020, 'DNB voorziet diepe economische crisis door pandemie', www.dnb.nl/ nieuws/nieuwsoverzicht-en-archief/persberichten-2020/dnb389042.jsp, geraadpleegd op 13 juni 2020.

Eindhovens Dagblad 28 maart 2020, 'Coronamaatregelen veroorzaken op langere termijn juist méér doden'; www.ed.nl/brabant/coronamaatregelen-veroorzaken-op-langeretermijn-juist-meer-doden a0f0aa10/120752997, geraadpleegd op 13 juni 2020.

Gupta 2020, 'Het koekoeksjong dat COVID heet', https://gupta-strategists.nl/studies/hetkoekoeksjong-dat-covid-heet; 13 juni 2020. Het rapport is ook in het Engels beschikbaar op https://gupta-strategists.nl/en/research/covid-goes-cuckoo, geraadpleegd op 17 juni 2020.

Huffpost 2 mei 2013, 'Unemployment Is Bad for Your Health', www.huffpost.com/entry/ unemployment-health_b_2616430, geraadpleegd op 8 oktober 2020. 
Ioannidis, J.P.A. 17 maart 2020, 'A fiasco in the making? As the coronavirus pandemic takes hold, we are making decisions without reliable data', www.statnews.com/ 2020/03/17/a-fiasco-in-the-making-as-the-coronavirus-pandemic-takes-hold-we-aremaking-decisions-without-reliable-data, geraadpleegd op 13 juni 2020.

Jortcast \#217 20 april 2020, 'Ira Helsloot: de koele rekenaar aan de zijlijn', www.nporadio1.nl/podcasts-uitgelicht/23202-jortcast-217-ira-helsloot-de-koelerekenaar-aan-de-zijlijn, geraadpleegd op 16 juni 2020.

Medisch Contact 1 april 2020, Henk Maassen, 'John Ioannidis over covid-19: "Maak beleid op basis van wetenschap"', www.medischcontact.nl/nieuws/laatste-nieuws/ nieuwsartikel/john-ioannidis-over-covid-19-maak-beleid-op-basis-vanwetenschap.htm, geraadpleegd op 16 juni 2020.

NPO Radio 122 april 2020, 'Forse toename doden en besmettingen door corona in verpleeghuizen', www.nporadio1.nl/gezondheid/23260-forse-toename-doden-enbesmettingen-door-corona-in-verpleeghuizen, geraadpleegd op 19 juni 2020.

NRC Handelsblad 10 april 2020, Floor Rusman \& Joris Kooiman, 'Lockdown ook economisch verdedigbaar - voorlopig', www.nrc.nl/nieuws/2020/04/10/lockdown-ookeconomisch-verdedigbaar-voorlopig-a3996561, geraadpleegd op 16 juni 2020.

NRC Handelsblad 24 april 2020, Philip de Witt Wijnen, 'Corona duwt begrotingstekort naar ruim 90 miljard', www.nrc.nl/nieuws/2020/04/24/corona-duwtbegrotingstekort-naar-ruim-90-miljard-a3997789, geraadpleegd op 16 juni 2020.

NRC Handelsblad 9 oktober 2020, 'Waarom laten we patiënten met andere ziekten overlijden?', www.nrc.nl/nieuws/2020/10/08/waarom-laten-we-patienten-met-andereziekten-overlijden-a4015291, geraadpleegd op 10 oktober 2020.

NRC Handelsblad 10 oktober 2020, Tom-Jan Meeus, 'Corona in het kabinet: groepsvorming, harde kritiek en een nerveuze premier', www.nrc.nl/nieuws/2020/10/10/ corona-in-het-kabinet-groepsvorming-harde-kritiek-en-een-nerveuze-premiera4015437, geraadpleegd op 11 oktober 2020.

NU.nl 14 juli 2020, 'Ondanks gedeeltelijke lockdown nauwelijks minder verkeersdoden', www.nu.nl/coronavirus/6051167/ondanks-gedeeltelijke-lockdown-nauwelijksminder-verkeersdoden.html, geraadpleegd op 14 juli 2020.

NZA 2020, 'Urgentielijst medisch-specialistische zorg', https://puc.overheid.nl/nza/doc/ PUC_306624_22/1, geraadpleegd op 13 juni 2020.

Public Health Wales 2020, 'Longstanding Illness Projection 2020/21 2022/23', zie www.publichealthnetwork.cymru/en/news/links-between-unemployment-due-tocoronavirus-and-longstanding-illnesses-explored-in-new-report.

RIVM 2014, De kosteneffectiviteit van interventies gericht op verslaving aan alcohol en middelen, RIVM Briefrapport 133499001/2014, www.rivm.nl/nieuws/behandelingenverslavingszorg-zijn-kosteneffectief.

RIVM 1 oktober 2020, Monitoring Sterftecijfers Nederland, www.rivm.nl/monitoringsterftecijfers-nederland.

RIVM 9 oktober 2020, 'Ontwikkeling COVID-19 in grafieken', zie www.rivm.nl/ coronavirus-covid-19/grafieken, geraadpleegd op 9 oktober 2020.

RTL Nieuws 16 maart 2020, 'Rutte tijdens historische toespraak: “We moeten dit met z'n allen doen"', www.rtlnieuws.nl/nieuws/nederland/artikel/5058561/rutte-toespraaknederland-coronavirus, geraadpleegd op 19 juni 2020.

RTL Nieuws 5 juni 2020, 'Aantal coronadoden boven de 6000, bijna de helft overleed in verpleeghuis', www.rtlnieuws.nl/nieuws/artikel/5144186/corona-dodensterfgevallen-overleden-verpleeghuis-ouderen, geraadpleegd op 8 juni 2020.

RVZ 2006, Zinnige en duurzame zorg, www.raadrvs.nl/documenten/publicaties/ 2006/06/07/zinnige-en-duurzame-zorg, geraadpleegd op 9 oktober 2020. 
Rijksoverheid (z.d.), Kwaliteit van wetten en regels, www.rijksoverheid.nl/onderwerpen/ wetgeving/kwaliteit-wetten-en-regels, geraadpleegd op 9 oktober 2020.

ScienceGuide 26 mei 2020, Sicco Knecht, 'Er werd te lange tijd blind gevaren op de adviezen van het OMT', www.scienceguide.nl/2020/05/er-werd-te-lange-tijd-blindgevaren-op-de-adviezen-van-het-omt, geraadpleegd op 16 juni 2020.

SWOV 2005, De waardering van bespaarde verkeersdoden, www.swov.nl/en/publication/dewaardering-van-bespaarde-verkeersdoden, geraadpleegd op 9 oktober 2020.

Trouw 9 februari 2019, 'Een flinke recessie zorgt (gek genoeg) voor een lager sterftecijfer', www.trouw.nl/nieuws/een-flinke-recessie-zorgt-gek-genoeg-voor-een-lagersterftecijfer b3824423, geraadpleegd op 9 oktober 2020.

Trouw 1 mei 2020, Wilma Kieskamp, 'Andere experts naast het OMT zijn voor het kabinet nog niet zo makkelijk te vinden', www.trouw.nl/binnenland/andere-experts-naasthet-omt-zijn-voor-het-kabinet-nog-niet-zo-makkelijk-te-vinden b3330617/? referer=https\%3A\%2F\%2Fwww.google.com\%2F, geraadpleegd op 16 juni 2020.

Trouw 9 juni 2020, 'Hoeveel levens de lockdown heeft gered? Dat is lastig te berekenen', www.trouw.nl/zorg/hoeveel-levens-de-lockdown-heeft-gered-dat-is-lastig-teberekenen bf44bf0a, geraadpleegd op 9 oktober 2020.

Volksgezondheidenzorg.info 2020, 'Aantal bedden in ziekenhuizen daalt', www.volksgezondheidenzorg.info/onderwerp/ziekenhuiszorg/cijfers-context/trendaanbod\#node-trend-aantal-ziekenhuisbedden, geraadpleegd op 18 juni 2020.

Wereldbank 28 mei 2020, 'Food Security and COVID-19', www.worldbank.org/en/topic/ agriculture/brief/food-security-and-covid-19, geraadpleegd op 17 juni 2020.

Wereldbank 8 juni 2020, 'The Global Economic Outlook During the COVID-19 Pandemic: A Changed World', www.worldbank.org/en/news/feature/2020/06/08/the-globaleconomic-outlook-during-the-covid-19-pandemic-a-changed-world, geraadpleegd op 13 juni 2020.

WFP 16 april 2020, 'Risk of hunger pandemic as coronavirus set to almost double acute hunger by end of 2020', https://insight.wfp.org/covid-19-will-almost-double-peoplein-acute-hunger-by-end-of-2020-59df0c4a8072, geraadpleegd op 17 juni 2020.

Wikipedia 8 april 2020, https://en.wikipedia.org/wiki/Value_of_life, geraadpleegd op 9 oktober 2020.

Wikipedia 29 mei 2020, https://nl.wikipedia.org/wiki/Alternatieve_kosten; 9 oktober 2020.

Wikipedia 27 juli 2020, 'Quality-adjusted life year'; zie https://nl.wikipedia.org/wiki/ Quality-adjusted_life_year, geraadpleegd op 9 oktober 2020.

ZorgDomein 2020, 'ZorgDomein heeft actuele cijfers over zorgbehandelingen die zich opstapelen door corona crisis', https://zorgdomein.com/nieuws/actuele-cijfersuitgestelde-zorg-coronavirus, geraadpleegd op 13 juni 2020. 